\title{
APLIKASI AIR KELAPA PADA PERKECAMBAHAN BENIH KALANGKALA (Listea garciae Vidal) DENGAN PERLAKUAN PERENDAMAN DAN PEMERAMAN
}

\author{
Marjenah $^{1}$, Paulus Matius ${ }^{2}$, Agustina Hura ${ }^{3}$ \\ 1,2,3 Laboratorium Silvikultur Fakultas Kehutanan Universitas Mulawarman, \\ Gedung B11 Lantai 2 Kampus Gunung Kelua Jl. Penajam Samarinda 75119, Indonesia. \\ E-Mail: marjenah_umar@yahoo.com
}

\begin{abstract}
ABSTRAK
Aplikasi Air Kelapa pada Perkecambahan Benih Kalangkala (Listea garciae Vidal) dengan Perlakuan Perendaman dan Pemeraman. Kalangkala (L. garciae Vidal) merupakan salah satu buah lokal Kalimantan yang belum tersentuh teknologi. Buah kalangkala merupakan buah musiman yang hanya ditemui setahun sekali pada waktu tertentu, bersama-sama dengan buah musiman lainnya. Selama ini petani mengambil buahnya dari tumbuhan yang hidup liar tanpa membudidayakannya. Penelitian ini bertujuan untuk mengetahui pengaruh perlakuan perendaman dan pemeraman terhadap persentase perkecambahan benih, daya kecambah, tipe perkecambahan, kelompok biji (rekalsitran atau ortodoks) laju perkecambahan, dan tinggi kecambah kalanglala (L. garciaeVidal). Penelitian ini dilaksanakan di persemaian Laboratorium Silvikultur, Universitas Mulawarman. Penelitian ini dirancang dengan mengikuti pola Rancangan Acak Lengkap faktorial dengan perlakuan terdiri dari faktor perendaman (A), terdiri dari tiga tingkatan $\mathrm{A}_{1}$ (1 hari), $\mathrm{A}_{2}$ (2 hari), dan $\mathrm{A}_{3}$ (3 hari) dan faktor pemeraman (B), tiga tingkatan $\mathrm{B}_{1}$ (1 hari), $\mathrm{B}_{2}$ (2 hari) dan $\mathrm{B}_{3}$ (3 hari). Dua faktor tersebut dikombinasikan dan terdapat sembilan kombinasi dengan 3 ulangan beserta kontrol (tanpa perlakuan) dengan 3 ulangan. Keseluruhan biji yang disemai adalah 450 biji. Hasil penelitian menunjukkan tingkat keberhasilan yang sangat baik dalam persentase hidup, dengan rata-rata mencapai 97\%, rataan daya kecambah terbaik terdapat pada kombinasi perlakuan perendaman air kelapa $\left(\mathrm{A}_{2}\right)$ selama 12 jam dengan pemeraman selama 1 , 2, dan 3 hari $\left(B_{1}, B_{2}, B_{3}\right)$ yaitu 98,67\%. Kemudian untuk laju perkecambahan terbaik pada $A_{1} B_{1}$ dengan laju 11 hari, dan untuk tinggi perkecambahan terbaik terdapat pada $A_{1} B_{2}$. Serta berdasarkan hasil pengukuran kadar air, benih $L$. garciae Vidal termasuk dalam kategori rekalsitran dan tipe perkecambahannya adalah hypogeal.
\end{abstract}

Kata kunci : Litsea garciae Vidal, Perendaman, Pemeraman, Perkecambahan.

\begin{abstract}
Application of Coconut Water to Kalangkala (Listea garciae Vidal) Seed Germination by Immersion and Curing Treatments. Kalangkala (Litsea garciae Vidal) is a local fruit in Kalimantan that has not been touched by technology. Kalangkala fruit is a seasonal fruit that is only found once a year at certain times, together with other seasonal fruits. So far, farmers take the fruit from nature that live in the wild without cultivating it. This research to find out the effect of application coconut water variations in soaking and ripening treatment on the percentage of seed germination, germinati on rate, sprout height and type of germinatioand knowing the water content for determining the type of seed Kalangkala included in the recalcitrant or orthodox group and the interaction of these two factors against germination. This research was conducted at the Silviculture Laboratory nursery, Mulawarman University.This study was designed by Completely Randomized Design factorial with treatment consisting of two factors namely: soaking factors (A), which consisted of three levels of $A_{1}=$ Soaking with running tap water, $A_{2}=$ Soaking in coconut water, $A_{3}=$ Soaking in plain water (cold), and ripening factor $(B)$, three levels $B_{1}\left(1\right.$ day), $B_{2}$ (2days) and $B_{3}(3$ days). Average percentage of life reaching $97 \%$, the best germination average was found in a combination of coconut water soaking treatment $\left(A_{2}\right)$ for 12 hours with ripening for 1,2 , and 3 days $\left(B_{1}, B_{2}, B_{3}\right)$ which is 98.67\%. Based on the results of measurements of water content, seeds of L. garciae Vidal included in the recalcitrant category and the type of germination is hypogeal.
\end{abstract}

Key words : Germination rate, Litsea garciae Vidal, Soaking, Ripening. 


\section{PENDAHULUAN}

Salah satu buah lokal Kalimantan yang belum tersentuh teknologi adalah buah kalangkala (L. garciae Vidal), buah kalangkala merupakan buah musiman yang hanya ditemui setahun sekali pada waktu tertentu, bersama-sama dengan buah musiman lainnya. Selama ini petani mengambil buahnya dari tumbuhan yang hidup liar tanpa membudidayakannya (Indriyani,2015).

Secara umum masyarakat suku Dayak Kenyah dan Punan mengkosumsi buah kalangkala (L. garciae Vidal) yang memiliki kelebihan dalam penggunaan tumbuhan sebagai obat ada beberapa cara, yaitu dikonsumsi secara langsung dan secara tidak langsung dengan perlakuan-perlakuan tertentu sebelum digunakan (Rahayu, dkk., 2007).

Jenis ini termasuk golongan tanaman keras/tahunan (perennial) ( $L$. garciae Vidal) yang mempunyai nama daerah engkala (Kalimantan Barat) dan Kalangkala (Kalimantan Selatan) merupakan tanaman buah yang termasuk dalam kelompok underutilized fruit. Mengingat semakin banyak terjadinya alih fungsi lahan, kemungkinan besar tumbuhan ini akan menjadi langka. Untuk itu perlu perhatian dan upaya dari pemerintah agar plasma nutfah yang ada di bumi Indonesia dapat dilestarikan (Parmar, 2013).

Untuk mengatasi hal tersebut yaitu dengan meningkatkan benih yang bermutu tinggi, meningkatkan perkecambahan pada biji atau benih kadaluarsa diperlukan perlakuan khusus yang dilakukan yaitu member perlakuan terhadap benih sebelum ditabur. Salah satu dari perlakuan khusus tersebut yaitu dengan melakukan perendaman dalam air kelapa muda dan lama perendaman tertentu yang sudah ditetapkan karena dalam air kelapa muda terkandung hormon auksin, sitokinin dan giberelin, yang ketiganya ini merupakan hormone yang bekerja secara sinergis dalam proses peningkatan pembelahan, pertumbuhan sel dan perkembangan kultur sel tanaman (Purdyaningsih, 2013).

Menurut Nurjannati (2017), pemeraman benih merupakan sebuah teknik yang menghubungkan hidrasi sampai terjadi proses perkecambahan, akan tetapi tidak terjadi pertumbuhan. Pemeraman membiarkan proses metabolik yang dibutuhkan untuk perkecambahan tanpa terjadi perkecambahan sesungguhnya selain itu teknik pemereman merupakan cara meningkatkan perkecambahan dan performansi/vigor, yang juga efektif untuk kondisi tercekam seperti cekaman air dan kadar garam. Peningkatan perkecambahan tampak pada laju perkecambahan yang tinggi, keserempakan, performansi, vigor bibit yang tinggi, dan meningkatnya ketahanan tanaman di lahan tercekam sehingga dilakukan usaha meningkatkan performa tanaman kalangkala dengan perlakuan pemeraman yang mutu benihnya dikuatirkan turun karena faktor lingkungan berupa stressair.

Perkecambahan merupakan proses pertumbuhan dan perkembangan embrio. Hasil perkecambahan ini adalah munculnya tumbuhan kecil dari dalambiji. Proses perubahan embrio saat perkecambahan adalah plumula tumbuh dan berkembang menjadi batang, dan radikula tumbuh dan berkembang menjadi akar (Istamar, 2018).

Kalangkala (L. garciae Vidal) yang memiliki keunggulan buahnya memiliki manfaat sebagai bahan pangan, juga sebagai tumbuhan obat tradisional bagi masyarakat, daunnya diekstrak sebagai minyak atsiri, batang pohon kayunya sebagai material bangunan dan yang belum umum diketahui adalah perlakuan (treatment) mengecambahkan benih kalangkala (L. garciae Vidal) agar benih 
berkecambah dan perkecambahan berlangsung cepat serta seragam sehingga berdasarkan penjelasan di atas dipandang perlu untuk melakukan penelitian tentang perkecambahan kalangkala untuk memepersiapkan konservasi jenis kalangkala (L. garciae Vidal).

Penelitian ini bertujuan untuk mengetahui pengaruh perlakuan perendaman dan pemeraman terhadap persentase perkecambahan benih, daya kecambah, tipe perkecambahan, kelompok biji (rekalsitran atau ortodoks) laju perkecambahan, dan tinggi kecambah kalanglala (L. garciaeVidal).

\section{METODA PENELITIAN}

\subsection{Tempat dan Waktu}

Peneltian ini dilaksanakan di Persemaian Fakultas Kehutanan Universitas Mulawarman Kampus Gunung Kelua Samarinda. Waktu yang diperlukan untuk penelitian \pm 6 bulan mulai dari persiapan penelitian, pelaksanaan penelitian, pengambilan data, pengolahan data dan penulisan naskah.

\subsection{Bahan dan Alat}

Adapun alat-alat yang digunakan untuk pelaksanaan penelitian: 1) Thermohygrometer type portable merkKrisbow type KW06-797, untuk mengukur suhu dan kelembapan, 2) lluminometer type $\mathrm{T}-1 \mathrm{H}$ merk Minolta, untuk mengukur Intensitascahaya; 3) Timbangan analitik untuk mengukur kadarair; 4) Termometer untuk mengukur suhu media tanaman yangdisangrai; 5) Ayakan untuk menyaringtanah; 6) Karung dan kain hitam untuk pemeraman biji; 7) Penggaris untuk mengukur tinggi kecambah; 8) ATK.
Bahan yang digunakan dalam penelitian antara lain: 1) Tanah (TopSoil); 2) Air untuk penyiraman danperendaman; 3) Air kelapa untuk perendaman; 4) Label untuk identitas objek dan membedakanperlakuan; 5) Polybag dengan ukuran $12.5 \mathrm{~cm} \mathrm{x}$ $12.5 \mathrm{~cm} \times 25 \mathrm{~cm}$ sebanyak $450 \mathrm{lembar}$, sebagai mengecambahkanbenih.

Objek Penelitian ini adalah benih kalangkala (L. garciae Vidal) yang diberi perlakuan peredaman dan pemeraman. Parameter yang diamati dalam penelitian ini adalah: 1) Persentase kecambah; 2) Daya kecambah; 3) Laju perkecambahan; 4) Tipe perkecambahan; 5) Tinggi kecambah; 6) Kadar air benih (untuk penentuan benih rekalsitrant/ortodoks).

\subsection{Rancangan Penelitian}

Penelitian ini dirancang dalam Rancangan Acak Lengkap Faktorial yang terdiri dari 2 faktor, yaitu faktor A (perendaman selama 12 jam) dan faktor B (Pemeraman).

Faktor A (Perendaman) terdiri dari 3 macam, yaitu: $A_{1}=$ Perendaman dengan air mengalir, $\mathrm{A}_{2}=$ Perendaman dengan air kelapa, $\mathrm{A}_{3}=$ Perendaman dengan air biasa (dingin). Faktor $B$ (Pemeraman) terdiri dari 3 level, yaitu; $\mathrm{B}_{1}=$ Pemeraman selama 1 hari, $\mathrm{B}_{2}=$ Pemeraman selama 2 hari, $\mathrm{B}_{3}=$ Pemeraman selama 3 hari.

Faktor A dan Faktor B dikombinasikan sehingga ada 9 kombinasi perlakuan dan ditambah 1 perlakuan kontrol. Setiap kombinasi perlakuan diulang 3 kali sehingga terdapat 30 satuan perlakuan. Setiap satuan perlakuan ditanami 15 benih kalangkala, sehingga ada 450 benih yang dikecambahkan yang menjadi objek penelitian.

Persiapan penelitian dimulai dengan pengisian polybag menggunakan media perkecambahan (topsoil) yang 
sudah disterilisasi dengan cara disangrai sampai $100^{\circ} \mathrm{C}$. Benih kalangkala yang diperoleh dari Kalimantan Selatan (Banjarmasin) dibersihkan dengan cara daging buah dan biji dipisahkan dan selanjutnya diseleksi sebanyak 450 biji untuk dikecambahkan.

Perlakuan perendaman air biasa dan pemeraman benih dilakukan dengan mengacu pada metode Marjenah (2015) dan metode perendaman dengan air kelapa mengacu pada metode Utomo (2006).

Untuk kontrol (tanpa perlakuan) sebanyak 45 benih dibersihkan kemudian dikering anginkan. Perlakuan pertama $\left(\mathrm{A}_{1}\right), 135$ benih direndam dalam air mengalirselama12 jam

malam).Perlakuankedua( $\left.\mathrm{A}_{2}\right), 135$ benih direndamdalamair kelapa selama 12 jam (1 malam). Perlakuan ketiga $\left(\mathrm{A}_{3}\right)$, 135 benih direndam dalamairbiasa(dingin)selama 12 jam (1 malam).

Perlakuan pemeraman, benih yang telah direndam dan ditiriskan dimasukkan ke dalam karung dan ditutup dengan menggunakan kain hitam (lembap) untuk diperam. Penggunaan kain berwarna hitam untuk memeram benih dikarenakan warna hitam merupakan warna penyerap sinar yang paling baik sehingga suhu dapat meningkat dan mempercepat proses metabolisme dalambenih. Lama pemeraman disesuaikan dengan perlakuan yang diberikan dan waktu yang ditentukan yaitu selama 1 hari, 2 hari dan 3 hari dengan kode $B_{1}, B_{2} B_{3}$. Setelah 1 hari diperam (untuk perlakuan pertama) benih diambil dari karung, demikian juga untuk pemeraman yang lain yaitu pemeraman selama 2 hari dan 3 hari.

Benih dikecambahkan ke dalam polybag dengan ukuran $12.5 \mathrm{~cm} \mathrm{x}$ $12.5 \mathrm{~cm} \times 25 \mathrm{~cm}$. Perkecambahan ini diulang sebanyak 3 kali (15 benih untuk masing-masing perlakuan). Jumlah polybag yang diisi sebanyak 450 polybag.

\section{HASIL PENELITIAN DAN PEMBAHASAN}

\subsection{Kondisi Iklim Mikro di Persemaian}

Kondisi tklim mikro di persemaian yang diukur selama penelitian perkecambahan benih kalangkala (Litsea garciae Vidal) dapat dilihat pada Tabel 1 di bawah ini.

Tabel 1. Kondisi Iklim Mikro di Persemaian Selama Penelitian Perkecambahan

\begin{tabular}{|c|c|c|c|}
\hline \multirow[t]{2}{*}{ Waktu Pengukuran } & \multicolumn{3}{|c|}{ Elemen Iklim Mikro yang diukur } \\
\hline & Intensitas Cahaya (\%) & Suhu $\left({ }^{\circ} \mathrm{C}\right)$ & RH (\%) \\
\hline Awal Penelitian & 26 & 29 & 83 \\
\hline Pertengahan Penelitian & 19 & 28 & 86 \\
\hline Akhir Penelitian & 17 & 28 & 85 \\
\hline Rataan & 21 & 28 & 85 \\
\hline
\end{tabular}

RH = Relative Humidity / Kelembapan relatif (\%) 
Pada tabel di atas dapat dilihat rekaman iklim mikro di persemaian yang berpengaruh terhadap proses perkecambahan benih kalangkala. Cahaya berpengaruh tidak langsung terhadap perkecambahan benih, tetapi intensitas cahaya berpengaruh langsung terhadap suhu dan kelembapan relatif. Intensitas cahaya berbanding lurus terhadap suhu, pada intensitas cahaya tinggi suhu juga akan tinggi. Sementara itu, intensitas cahaya berbanding terbalik terhadap kelembapan relatif, pada intensitas cahaya rendah kelembapan relatif akan tinggi.

Suhu rataan di persemaian selama penelitian berlangsung adalah $28^{\circ} \mathrm{C}$. Kondisi ini merupakan kondisi yang menguntungkan untuk perkecambahan benih. Suhu sangat mempengaruhi kecepatan proses permulaan perkecambahan.Sebagaimana

dikemukakan oleh Sutopo (2002), bahwa suhu optimal yang paling menguntungkan dalam perkecambahan benih yaitu pada kisaran suhu antara $26,5^{\circ} \mathrm{C}-35^{\circ} \mathrm{C}$.
Kelembapan udara relatif merupakan jumlah kandungan uap air di udara pada suatu saat dibandingkan dengan kondisi uap air jenuh. Kelembapan relatif udara rataan di persemaian selama penelitian berlangsung adalah 85\%. Kelembapan udara yang mengandung uap air yang tinggi merupakan kondisi yang paling disukai untuk berlangsungnya perkecambahan. Perkembangan benih tidak akan dimulai bila air belum terserap masuk ke dalam benih.

\subsection{Persentase Kecambah}

Persentase kecambah adalah ratio antara benih yang mampu berkecambah dan hidup dengan benih yag ditabur diawal penelitian. Persentase kecambah kalangkala (Litsea garciae Vidal) setelah dua bulan penelitian dengan perbedaan faktor perlakuan terhadap benih terdiri dari faktor perendaman (A), yang terdiri dari tiga tingkatan dan faktor pemeraman (B), yang terdiri dari tiga teknik pemeraman dapat dilihat pada Tabel 2 berikut.

Tabel 2. Rataan Persentase Kecambah (\%) Benih Kalangkala (L. garciae Vidal) Berdasarkan Kombinasi Perlakuan Perendaman dan Pemeraman

\begin{tabular}{crcc}
\hline Kombinasi Perlakuan & \multicolumn{2}{c}{ Jumlah Semai } & Persen Hidup (\%) \\
& Tanam & Berkecambah & 89 \\
$\mathrm{~A}_{0} \mathrm{~B}_{0}$ & 45 & 40 & 91 \\
$\mathrm{~A}_{1} \mathrm{~B}_{1}$ & 45 & 41 & 100 \\
$\mathrm{~A}_{1} \mathrm{~B}_{2}$ & 45 & 45 & 100 \\
$\mathrm{~A}_{1} \mathrm{~B}_{3}$ & 45 & 45 & 98 \\
$\mathrm{~A}_{2} \mathrm{~B}_{1}$ & 45 & 44 & 100 \\
$\mathrm{~A}_{2} \mathrm{~B}_{2}$ & 45 & 45 & 98 \\
$\mathrm{~A}_{2} \mathrm{~B}_{3}$ & 45 & 44 & 100 \\
$\mathrm{~A}_{3} \mathrm{~B}_{1}$ & 45 & 45 & 100 \\
$\mathrm{~A}_{3} \mathrm{~B}_{1}$ & 45 & 45 & 93 \\
$\mathrm{~A}_{3} \mathrm{~B}_{3}$ & 45 & 42 & - \\
Total & 450 & 436 & 97 \\
\hline Rataan & & & 4,22 \\
\hline Standar Deviasi
\end{tabular}


Pada tabel di atas dapat dilihat bahwa rataan persentase kecambah benih kalangkala adalah $(97 \pm 4,22) \%$. Pada semua kombinasi perlakuan hampir mendekati $100 \%$. Hal ini menunjukkan bahwa perlakuan pada benih sebelum dikecambahkan berpengaruh terhadap persentase hidup kecambah kalangkala. Beberapa kombinasi perlakuan $\left(\mathrm{A}_{1} \mathrm{~B}_{2}\right.$, $\mathrm{A}_{1} \mathrm{~B}_{3}, \mathrm{~A}_{2} \mathrm{~B}_{2}, \mathrm{~A}_{3} \mathrm{~B}_{1}$ dan $\mathrm{A}_{3} \mathrm{~B}_{1}$ ) mencapai $100 \%$.

Kombinasi perlakuan seperti $\mathrm{A}_{1} \mathrm{~B}_{2}$ (air mengalir, diperam 2 hari), $\mathrm{A}_{1} \mathrm{~B}_{3}$ (air mengalir, diperam 3 hari) yang menunjukkan $100 \%$ karena perendaman yang berlangsung dalam air mengalir berfungsi untuk mencuci zat-zat yang menghambat proses perkecambahan dan melunakkan kulit biji sehingga menjamin keberhasilan persentase hidup kecambah. Kemudian pada kombinasi perlakuan $\mathrm{A}_{2} \mathrm{~B}_{2}$ (air kelapa,diperam 2 hari) juga menunjukkan $100 \%$ karena selain sebagai Zat Pengatur Tumbuh (ZPT), air kelapa juga berfungsi untuk mencuci atau membersihkan zat-zat yang menghambat perkecambahan benih.

Air kelapa selain mengandung hormon alami sitokinin dan auksin yang dapa tmembantu proses pembelahan sel, pemanjangan sel, induksi akar, dan induksi tunas juga mengandung vitamin, sukrosa, dan mineral yang dibutuhkan untuk membantu proses pertumbuhan tunas dan akar (Suryanto, 2009)

Pada kombinasi perlakuan seperti $\mathrm{A}_{3} \mathrm{~B}_{1}$ (perendaman air biasa selama 12 jam ,diperam 1 hari), $A_{3} B_{2}$ (perendaman air biasa selama 12 jam,diperam 2 hari) menunjukkan perkecambahan $100 \%$ karena air biasa juga berperan mencuci zat-zat penghambat dalam benih sehingga menjamin benih dapat berkecambah.

\subsection{Daya Kecambah}

Daya kecambah merupakan ratio antara jumlah benih yang berkecambah dan benih yang tersisa dan masih sehat (tetapi tidak berkecambah) dengan jumlah benih yang ditanam. Berdasarkan hasil pengukuran jumlah kecambah $L$. garciae Vidal setelah dua bulan diketahui daya kecambah rata-rata untuk setiap perlakuan dapat dilihat pada Tabel 3 berikutini:

Tabel 3. Rataan Daya Kecambah (\%) Benih Kalangkala (L. garciae Vidal) Berdasarkan Kombinasi Perlakuan Perendaman dan Pemeraman.

\begin{tabular}{|c|c|c|c|c|c|}
\hline \multirow[t]{2}{*}{ Perendaman (A) } & \multicolumn{4}{|c|}{ Pemeraman (B) } & \multirow{2}{*}{$\begin{array}{c}\text { Rataan } \\
(\%)\end{array}$} \\
\hline & B0 & B1 & $\mathrm{B} 2$ & B3 & \\
\hline $\mathrm{A} 0$ & 89 & - & - & - & 89 \\
\hline A1 & - & 91 & 100 & 100 & 97 \\
\hline $\mathrm{A} 2$ & - & 98 & 100 & 98 & 98.67 \\
\hline A3 & - & 100 & 100 & 93 & 97,67 \\
\hline Rataan & 89 & 96,33 & 100 & 97 & 95,59 \\
\hline
\end{tabular}

Tabel di atas menunjukkan bahwa rata-rata daya kecambah terbaik terdapat pada kombinasi perlakuan perendaman $\mathrm{A}_{2}$ (air kelapa) dengan pemeraman $\left(\mathrm{B}_{1} \mathrm{~B}_{2}\right.$ $\left.\mathrm{B}_{3}\right)$ 1, 2 dan 3 hari yaitu rataan $98,67 \%$ hal ini diduga karena air kelapa mengandung hormon yang berperan mencuci zat-zat yang menghambat perkecambahan serta merangsang terjadinya proses perkecambahan yang disebut daya kecambah (kemampuan suatu benih untuk berkecambah dalam hal memunculkan radikula).

Dalam air kelapa terdapat 2 hormon alami yaitu auksin dan sitokinin sebagai pendukung pembelahan sel embrio kelapa. Zat Pengatur Tumbuh (ZPT) disebut sebagai substansi bahan 
organik (selain vitamin dan unsur makro) yang dalam jumlah sedikit akan merangsang, menghambat atau sebaliknya mengubah proses fisiologi. Hormon tumbuhan merupakan bagian dari proses regulasi genetik dan berfungsi sebagai prekursor. Rangsangan lingkungan memicu terbentuknya hormon tumbuhan bila konsentrasi hormone telah mencapai tingkat tertentu, sejumlah gen yang semula tidak aktif akan mulai ekspresif (Azwar, 2008)

Perlakuan awal atau pendahuluan merupakan hal penting yaitu istilah yang digunakan untuk kondisi atau proses yang diterapkan pada pematahan dormansi untuk perkecambahan. Tujuan perlakuan awal adalah untuk menjamin bahwa benih akan berkecambah, dan bahwa perkecambahan berlangsung cepat dan seragam. Metode perlakuan awal sering harus disesuaikan dengan individu jenis dan lot benih berdasarkan pengalaman dan percobaan-percobaan (Schmidth, 2002).

\subsection{Laju Perkecambahan}

Laju perkecambahan merupakan ratio antara jumlah benih berkecambah pada satuan waktu tertentu dengan jumlah total benih yang berkecambah. Berdasarkan hasil pengukuran laju perkecambahan benih kalangkala ( $L$. garciae Vidal), dua bulan diketahui laju rata-rata kecambah untuk setiap perlakuan dapat dilihat pada Gambar 1 berikut.

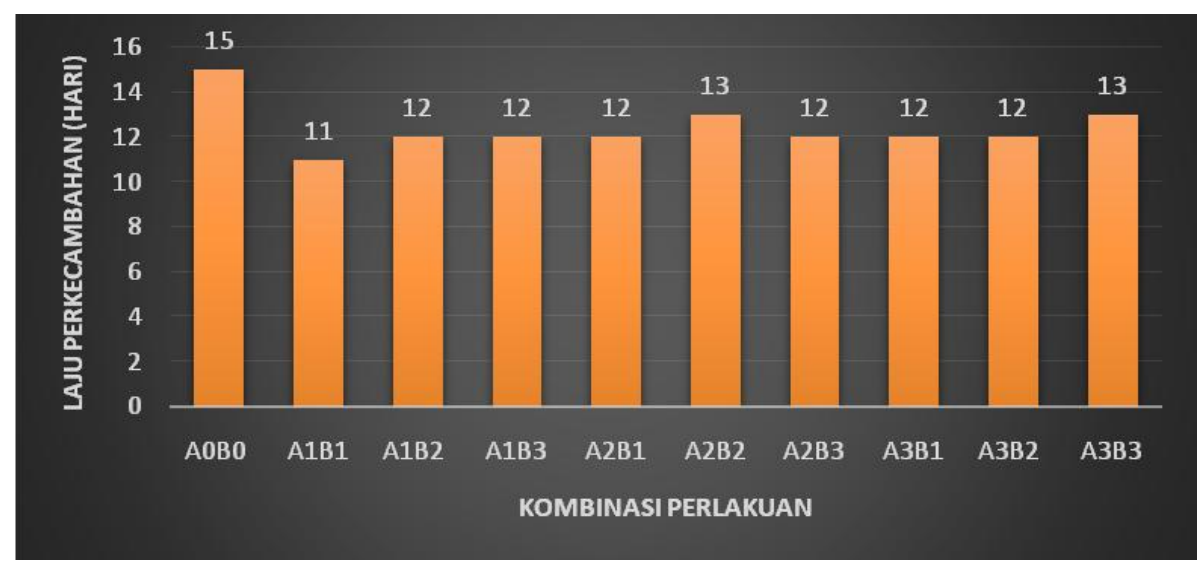

Gambar 1. Diagram Batang Laju Perkecambahan Kalangkala (L. garciae Vidal) Pada Kombinasi Perlakuan Perendaman dan Pemeraman

Dari data di atas yang disajikan dalam diagram batang dapat dilihat bahwa laju perkecambahan yang tercepat terjadi pada kombinasi perendaman air mengalir dan pemeraman 1 hari $\left(\mathrm{A}_{1} \mathrm{~B}_{1}\right)$ dengan ratarata yaitu 11 hari. Kemudian tercepat kedua yaitu dengan rata-rata 12 hari terjadi pada kombinasi perlakuan perendaman air mengalir dengan pemeraman 2 hari $\left(\mathrm{A}_{1} \mathrm{~B}_{2}\right)$, perlakuan perendaman air mengalir dengan pemeraman 3 hari $\left(\mathrm{A}_{1} \mathrm{~B}_{3}\right)$, perlakuan perendaman air kelapa dengan pemeraman 1 hari $\left(\mathrm{A}_{2} \mathrm{~B}_{1}\right)$, perlakuan perendaman air kelapa dengan pemeraman 3 hari $\left(\mathrm{A}_{2} \mathrm{~B}_{3}\right)$, perlakuan perendaman air biasa dengan pemeraman 1 hari $\left(\mathrm{A}_{3} \mathrm{~B}_{1}\right)$, perendaman air biasa dengan pemeraman 2 hari $\left(\mathrm{A}_{3} \mathrm{~B}_{2}\right)$, kemudian tercepat ketiga terjadi pada kombinasi perlakuan perendaman air kelapa dan pemeraman 2 hari $\left(\mathrm{A}_{2} \mathrm{~B}_{2}\right)$ dan perlakuan perendaman air biasa 
dengan pemeraman 3 hari $\left(A_{3} B_{3}\right)$ yaitu dengan rata-rata 13 hari. Sedangkan rata-rata laju perkecambahan terlama terjadi pada tanpa perlakuan $\left(\mathrm{A}_{0} \mathrm{~B}_{0}\right)$ yaitu 15 hari.

Perbedaan ini muncul karena air mengalir melarutkan bahan-bahan yang membungkus biji sehingga proses imbibisi dapat berlangsung lebih cepat, selain itu juga terjadi proses pergantian air, baik suhu maupun tekanan melalui aliran air sehingga terjadi proses imbibisi terhadap benih sehingga poripori biji terbuka dan memudahkan proses masuknya air ke dalam biji, serta pemeraman untuk memudahkan pemunculan radikula dengan cepat meningkatkan keseragaman perkecambahan seperti laju perkecambahan, sehingga perlakuan $\mathrm{A}_{1} \mathrm{~B}_{1}$ (perendaman air mengalir selama 12 jam dan pemeraman selama satu hari) terhadap benih yaitu pada hari ke11 lebih efektif dibandingkan $\mathrm{A}_{0} \mathrm{~B}_{0}$ tanpa perlakuan.

Imbibisi adalah proses masuknya

air kedalam pori-pori biji dan menyebabkan biji menggembung dan kulit biji menjadi lunak yang akan memudahkan radikula menembus kulit biji (Jayanti, 2017). Utomo (2006) menyatakan bahwa pemeraman adalah metode mempercepat dan menyeragamkan perkecambahan, melalui pengontrolan penyerapan sehingga perkecambahan dapat terjadi, namun tidak mencukupi untuk munculnya akar. Pemeraman membuat perkecambahan lebih dari sekedar imbibisi yakni sedekat mungkin pada fase ketiga yakni fase pemanjangan akar pada perkecambahan selama pemeraman keragaman dalam tingkat penyerapan awal dapat diatasi.

Selanjutnya untuk mengetahui pengaruh kombinasi perlakuan perendaman dan pemeraman yang berbeda terhadap laju perkecambahan kalangkala (LitseagarciaeVidal) maka perlu dilakukan uji statistik menggunakan sidik ragam dengan hasil ditampilkan pada Tabel 4 di bawah ini :

Tabel 4. Bagan Sidik Ragam Analysis Of Varian (ANOVA) Laju Perkecambahan (hari) Kalangkala ( $L$. garciae Vidal) Berdasarkan Kombinasi Perendaman dan Pemeraman.

\begin{tabular}{ccccccc}
\hline $\begin{array}{c}\text { Sumber } \\
\text { Keragaman }\end{array}$ & $\begin{array}{c}\text { Derajat } \\
\text { Bebas }\end{array}$ & $\begin{array}{c}\text { Jumlah } \\
\text { Kuadrat }\end{array}$ & $\begin{array}{c}\text { Kuadrat } \\
\text { Rataan }\end{array}$ & F - Hitung & \multicolumn{2}{c}{ F - Tabel } \\
\hline Perlakuan & 8 & 5,41572 & 0,67697 & $1,68432^{\text {ns }}$ & 3,55456 & 6,01290 \\
A & 2 & 2,74507 & 1,37254 & $3,41493^{\text {ns }}$ & 3,55456 & 6,01290 \\
B & 2 & 1,52626 & 0,08479 & $0,21097^{\text {ns }}$ & 2,92774 & 4,57904 \\
AB & 4 & 1,14439 & 0,06358 & $0,15818^{\text {ns }}$ & - & - \\
Galat & 18 & 7,23459 & 0,40192 & - & - & - \\
Total & 26 & 12,65031 & & - & - & - \\
\hline
\end{tabular}

Keterangan: ns : Tidak berbeda nyata

Dari perhitungan dengan sidik ragam, hasil perhitungan yaitu faktor $\mathrm{A}$ (perendaman) tidak menunjukkan pengaruh yang berbeda nyata, faktor B (pemeraman) juga tidak menunjukkan pengaruh yang berbeda nyata. Demikian pula dengan kombinasi perendaman dengan pemeraman tidak member pengaruh nyata terhadap laju perkecambahan L.garciae Vidal 
sehingga tidak dilanjutkan uji Beda Nyata Terkecil/BNT (Least Significant difference/LSD).

\subsection{Tinggi Kecambah}

Kecambah adalah batas antara biji dan semai. Kecambah sudah tidak lagi bisa disebut biji karena bentuknya sudah berubah dan sudah memiliki plumula dan radikula. Tetapi, kecambah belum bisa disebut sebagai semai karena masih belum mampu melakukan fotosintesis dan hidupnya masih bergantung pada cadangan makanan yang dibawanya (kotiledon).

Pertumbuhan tinggi digunakan untuk menggambarkan perubahan bentuk terhadap suatu kecambah, salah satunya yaitu tinggi kecambah sebagai respon dari perlakuan yang diberikan kepada benih sebelum dikecambahkan. Pertumbuhan tinggi menunjukkan perubahan tinggi kecambah yang diperoleh dari perhitungan tinggi kecambah L. garciae Vidal dari awal hingga akhir pengamatan penelitian. Hasil pengamatan yang telah dilakukan selama 2 bulan penelitian terhadap pertambahan tinggi kecambah $L$. garciae Vidal dengan sembilan kombinasi perlakuan perendaman dan pemeraman, dapat dilihat pada Gambar 2.

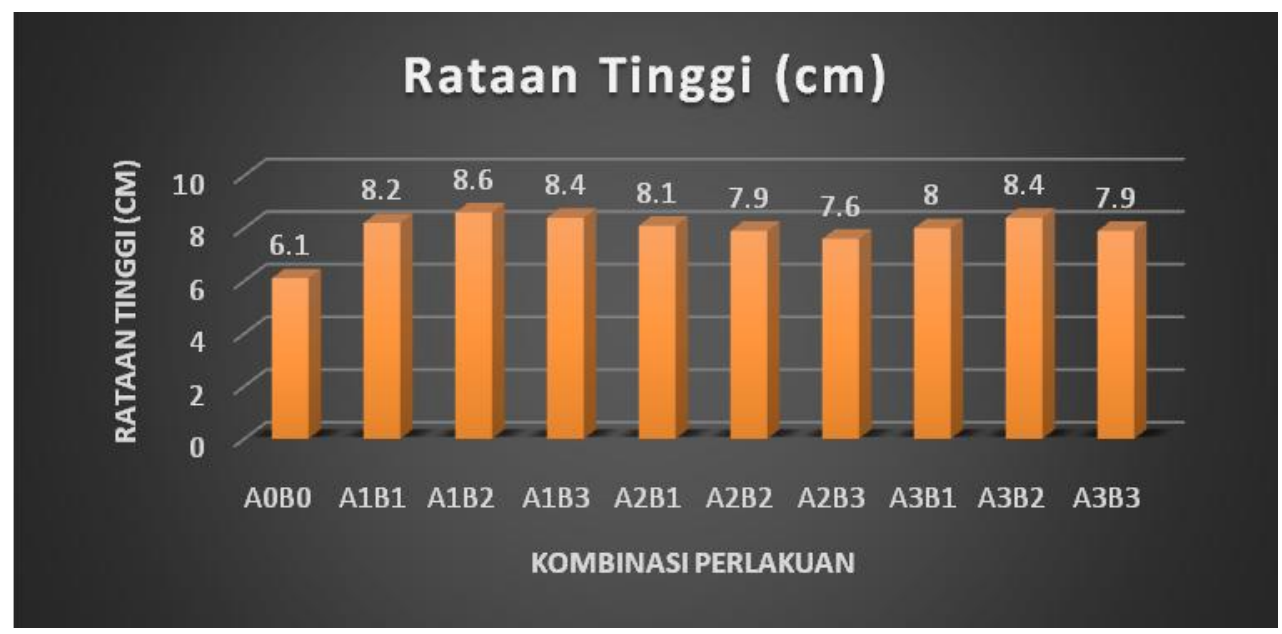

Gambar 2. Diagram Batang RataanTinggi Kecambah Kalangkala (L.garciaeVidal) Berdasarkan Kombinasi Perendaman dan Pemeraman.

Dari data yang disajikan dalam diagram batang (Gambar 2) dapat dilihat bahwa rataan tinggi perkecambahan tertinggi terjadi pada kombinasi perlakuan perendaman air mengalir dengan pemeraman dua hari $\left(\mathrm{A}_{1} \mathrm{~B}_{2}\right)$, meskipun rataan tinggi pada kombinasi perlakuan air mengalir dengan pemeraman satu hari $\left(\mathrm{A}_{1} \mathrm{~B}_{1}\right)$ dan kombinasi perlakuan air mengalir dengan pemeraman tiga hari $\left(\mathrm{A}_{1} \mathrm{~B}_{3}\right)$ juga menunjukkan rataan yang relatif seragam hampir mendekati $\left(\mathrm{A}_{1} \mathrm{~B}_{2}\right)$ begitu juga dengan kombinasi perlakuan yang lainnya menunjukkan data rataan tinggi dibanding rataan tinggi perkecambahan yang terendah terjadi pada kontrol tanpa perlakuan $\left(\mathrm{A}_{0} \mathrm{~B}_{0}\right)$.

Perbedaan ini muncul karena perendaman yang berlangsung lama dalam air selama satu sampai beberapa hari berfungsi untuk mencuci zat-zat yang menghambat dan melunakkan kulit biji memunculkan radikula serta pemeraman yang dapat menyeragamkan 
proses perkecambahan, dibandingkan yang tanpa perlakuan.

Untuk mengetahui pengaruh kombinasi perlakuan perendaman yang berbeda terhadap rata-rata tinggi perkecambahan kalangkala (L. garciae Vidal) maka perlu dilakukan uji statistik menggunakan sidik ragam dengan hasil ditampilkan pada Tabel 4 berikut.

Tabel 4. Bagan Sidik Ragam Analysis Of Varian (ANOVA) Rataan Tinggi Kecambah (cm) L.garciae Vidal Berdasarkan Kombinasi Perendaman dan Pemeraman.

\begin{tabular}{ccccccc}
\hline \multirow{2}{*}{$\begin{array}{c}\text { Sumber } \\
\text { Keragaman }\end{array}$} & $\begin{array}{c}\text { Derajat } \\
\text { Bebas }\end{array}$ & $\begin{array}{c}\text { Jumlah } \\
\text { Kuadrat }\end{array}$ & \multirow{2}{*}{$\begin{array}{c}\text { Kuadrat } \\
\text { Rataan }\end{array}$} & F-Hitung & \multicolumn{2}{c}{ F-Tabel } \\
\cline { 6 - 7 } & & & & & 0.05 & 0.01 \\
\hline Perlakuan & 8 & 2,254016 & 0,281752 & $1,512951^{\mathrm{ns}}$ & 3,55456 & 6,012905 \\
$\mathrm{~A}$ & 2 & 1,122189 & 0,561095 & $3,012963^{\mathrm{ns}}$ & 3,55456 & 6,012905 \\
$\mathrm{~B}$ & 2 & 0,526012 & 0,029223 & $0,156921^{\mathrm{ns}}$ & 2,92774 & 4,579036 \\
$\mathrm{AB}$ & 4 & 0,605815 & 0,033656 & $0,180728^{\mathrm{ns}}$ & & \\
Galat & 18 & 3,352083 & 0,186227 & & & \\
& & & & & & \\
Total & 26 & 5,606099 & & & & \\
\hline
\end{tabular}

Keterangan : ns : tidak signifikan

Dari Tabel 4 yang telah dilakukan perhitungan dengan sidik ragam, hasil perhitungan yaitu faktor A (perendaman) tidak menunjukkan pengaruh yang berbeda nyata, faktor $\mathrm{B}$ (pemeraman) juga tidak menunjukkan pengaruh yang berbeda nyata begitu pula dengan interaksi faktor A dan faktor B. Hal ini disebabkan perlakuan perendaman; pemeraman; dan kombinasi perendaman dengan pemeraman memberi pengaruh yang hampir sama terhadap tinggi kecambah L. garciae Vidal. Pada keadaan seperti ini, semua perlakuan dan kombinasinya dapat dilakukan untuk perkecambahan L. garciae Vidal. Karena hasil uji menunjukkan tidak signifikan, maka tidak perlu dilanjutkan Uji Beda Nyata Terkecil/BNT (Least Significant difference/LSD)

\subsection{Tipe Perkecambahan}

Keberhasilan perkecambahan ditandai dengan proses munculnya radikula dari suatu biji yang memiliki dua tipe yaitu benih tetap di bawah permukaan tanah dan di atas permukaan tanah. Dari pertumbuhan awal suatu kecambah, tipe perkecambahan dapat dibedakan atas:

a Tipe perkecambahan epigeal (epigeous) dimana munculnya radikula diikuti dengan memanjangnya hipokotil secara keseluruhan dan membawa serta kotiledon dan membawa serta kotiledon dan plumula ke atas permukaan tanah.

b. Tipe perkecambahn hypogeal (hipogeous) dimana munculnya radikula diikuti dengan pemanjangan plumula, hipokotil tidak memanjang ke atas permukaan tanah, sedangkan kotiledon tetap berada di dalam kulit biji dibawah permukaan tanah.

c. Tipe semi hypogeal kombinasi dari perkecambahan hipogeal dan epigeal yakni kotiledon berkembang seperti 
pada epigeal namun hipokotil tidak memanjang atau tidak berkembang.

d. Tipe durian, hipokotil akan memanjang tetapi kotiledon tidak berkembang (durian, lai, dipterocarpus, dll).

Pada perkecambahan benih $L$. garciae Vidal diawali dengan munculnya plumula ke atas permukaan tanah sedangkan kotiledonnya tetap di bawah permukaan tanah, perkecambahan ini termasuk dalam tipe perkecambahan hypogeal. Pada saat perkecambahan berlangsung biji terbelah menjadi dua dan kedua-duanya mengeluarkan radikula. Biji yang demikian adalah biji yang bersifat poliembrionik, artinya dalam satu biji memiliki lebih dari satu embrio.

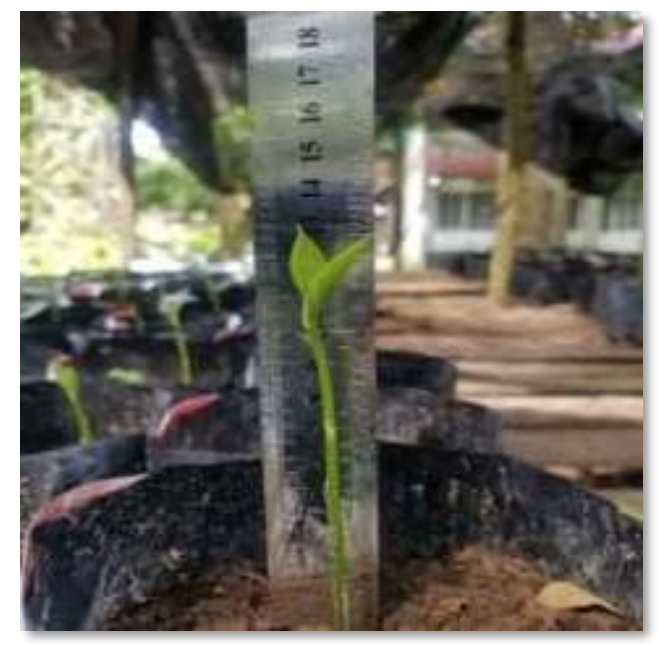

(a)

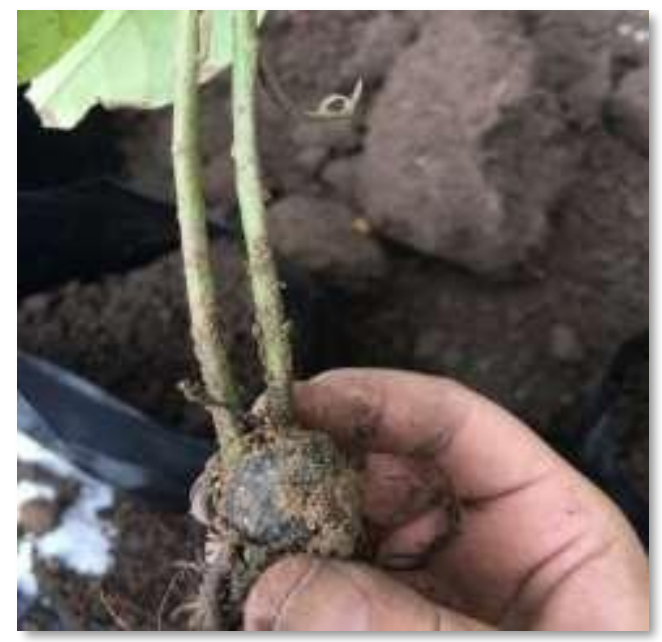

(b)

Gambar 3. Kecambah L.garciae Vidal (a) dan contoh biji poliembrionik (b)

\subsection{Kadar Air Benih}

Kadar air benih adalah ratio antara berat benih kering dengan berat benih basah. Benih L. garciae Vidal dari $1 \mathrm{~kg}$ terdapat 100 - 115 buah, untuk mengetahui kadar air benih diambil 10 sampel sebagai bahan uji. Pengujian dilakukan dengan metode pengeringan benih menggunakan oven dengan suhu $80^{\circ} \mathrm{C}$ selama 24 jam dan data kadar air benih konstan yang diperoleh dapat dilihat pada Tabel 5 berikut. 
Tabel 5. Rataan Kadar Air (\%) Benih Kalangkala (L. garciae Vidal)

\begin{tabular}{cccc}
\hline No & $\begin{array}{c}\text { Berat } \\
\text { Basah }(\mathbf{g})\end{array}$ & $\begin{array}{c}\text { Berat } \\
\text { Kering }(\mathbf{g})\end{array}$ & $\begin{array}{c}\text { Kadar Air Benih } \\
(\boldsymbol{\%})\end{array}$ \\
\hline 1 & 2,4 & 0,8 & 66,67 \\
\hline 2 & 2,3 & 0,7 & 69,57 \\
\hline 3 & 1,2 & 0,5 & 58,33 \\
\hline 4 & 1,8 & 0,6 & 66,67 \\
\hline 5 & 1,6 & 0,6 & 62,50 \\
\hline 6 & 1,7 & 0,4 & 76,47 \\
\hline 7 & 1,9 & 0,7 & 63,16 \\
\hline 8 & 2,9 & 1,2 & 58,62 \\
\hline 9 & 1,8 & 0,7 & 61,11 \\
\hline 10 & 1,3 & 0,4 & 69,23 \\
\hline Rata-rata & 1,89 & 0,66 & 65,08 \\
\hline Standar Deviasi & & & 5,34
\end{tabular}

Berdasarkan data rataan kadar air benih yang disajikan dalam tabel di atas yaitu $65.08 \pm 5,34 \%$ hasil dari 10 sampel yang dioven dengan suhu $80^{\circ} \mathrm{C}$ menunjukkan kandungan kadar air benih kalangkala relative tinggi. Berdasarkan kandungan kadar air benih kalangkala, maka dapat dikatakan bahwa biji/benih kalangkala termasuk dalam kategori rekalsitran

Benih rekalsitran adalah struktur benih yang banyak mengandung air sehingga dalam proses penyimpanannya membutuhkan kadar air yang relatif tinggi. Benih yang sudah gugur dari induknya masih dalam kondisi lembap dan akan mati apabila kadar air kritis. Benih rekalsitran memiliki daya hidup yang relative pendek walaupunbenih disimpan pada kondisi lembab (Hasanah, 2002). Hal ini juga dikemukan oleh Hadad et al. (2006), pada saat masak fisiologis kadar air benih rekalsitran berkisar antara $50 \%$ sampai $70 \%$ karena tidak mengalami maturation drying seperti benih ortodoks.

\section{KESIMPULAN}

Dari hasil penelitian terhadap perkecambahan benih kalangkala (Litsea garciae Vidal), dapat ditarik kesimpulan sebagai berikut:

Kombinasi perendaman dan pemeraman berpengaruh terhadap persentase hidup kecambah kalangkala (Litsea garciaeVidal). Kombinasi perendaman dan pemeraman yang terbaik untuk daya kecambah terjadi pada 3 perlakuan kombinasi yaitu kombinasi perendaman air kelapa dan diperam selama 1 hari (98\%), perendaman dengan air dan diperam selama 2 hari $(100 \%)$, air kelapa dan diperam selama 3 hari $(98 \%)$ serta dengan rataan keseluruhan yaitu $98,67 \%$.

Kombinasi perendaman dan pemeraman yang terbaik untuk laju perkecambahan terjadi pada kombinasi perlakuan perendaman air mengalir selama 1 hari, dengan pemeraman selama 1 hari yaitu 11 hari. 
Kombinasi perendaman dan pemeraman yang terbaik untuk pertumbuhan tinggi kecambah terjadi pada kombinasi perlakuan perendaman air mengalir selama 1 hari, dengan pemeraman selama 2 hari yaitu $8,6 \mathrm{~cm}$.

Tipe perkecambahan L. garciae Vidal adalah hypogeal. Kadar air benih L. garciae Vidal $65,08 \%$ termasuk dalam kategori rekalsitran.

\section{DAFTAR PUSTAKA}

Azwar. (2008). Air Kelapa Pemacu Pertumbuhan Anggrek. Published On

http://perpustakaan.fmipa.unpak.ac. id. Diakses Tanggal 15 Februari 2018 Pukul 17.24 Wita.

Hadad EA, E. Randriani, N. Heryana. (2006). Perbaikan Budidaya dan Mutu Hasil Tanaman Pala (Myristica fragrans Houtt). Sukabumi (ID): Balai Penelitian Tanaman Rempah dan Aneka Tanaman Industri.

Hasanah M. (2002). Peran mutu fisiologik benih dan pengembangan industri benih tanaman industri. Jurnal Litbang Pertanian, 21 (3), 2002. Hal. 84 91.

Indriyani. (2015). Litsea Garciae Vidal Buah Eksotik Dari Kalimantan. Published $\mathrm{On}$ http://balittra.litbang.pertanian.go.i d. Diakses Tanggal 22 Januari 2018 Pukul 14.20 Wita.

Istamar, S. (2018). Proses Perkecambahan. Published On https:// www.akh mad share.com. Diakses Tanggal 04 april 2019.Pukul 08.28 Wita.

Jayanti, W. (2017). Pengaruh Air Kelapa (Cocos nucifera L.) Terhadap
Perkecambahan Dan Pertumbuhan Kecambah Biji Kakao (Theobroma cacao L.). Published On http://digilib.unila.ac.id. Diakses Tanggal 12 Mei 2018 Pukul 17.45 Wita.

Marjenah. (2015). Manajemen Pembibitan (Edisi Revisi). Samarinda: Mulawarman University Press.

Nurjannati,K.(2017).Efek Perlakuan Priming Terhadap Performa Tanaman Cabai (Capsicum annuum L.) Pada Kondisi Stres Air. Published On http:// eprints. uny. ac. id/ 53490/1/ SKRIPSI.pdf. Diakses Tanggal 18 April 2018 Pukul 19.35Wita.

Parmar,C.F.(2013).Litsea garciae Vidal. Buah Eksotik dari Kalimantan. Published On http://www.fruitipedia.com/engkal a_litsea_garciae.htm\%3E. Diakses Tanggal 30 April 2018 Pukul. 09.00Wita.

Purdyaningsih, E. (2013). Kajian Pengaruh Pemberian Air Kelapa Dan Urine Sapi Terhadap Pertumbuhan Stek Nilam. Balai Besar Perbenihan Dan Proteksi Tanaman Perkebunan. Published On http://repository.utu.ac.id. Diakses Tanggal 7 Maret 2018 Pukul 21.54Wita.

Rahayu, Y.D, Sutedjo, P. Matius. (2007). Kajian Potensi Tumbuhan Obat Di Kawasan Malinau Research Forest (MRF) Cifor Kabupaten Malinau Kalimantan Timur. Jurnal Kehutanan Indonesia. 3 (1), April 2007. Hal. 87 - 101.

Schmidth, L. (2002). Pedoman Penanganan Benih Tanaman Hutan Tropis Dan Subtropis. Jakarta: Direktorat Jendral Rehabilitasi 
Lahan Dan Perhutanan Sosial Departemen Kehutanan.

Suryanto, E. (2009). Air Kelapa Dalam Media Kultur Anggrek. Erlangga.

Published On http://digilib.unila.ac.id.Diakses Tanggal 12 Mei 2018 Pukul 17.45 Wita
Sutopo. L. (2002). Teknologi Benih. Jakarta: PT. Raja Grafindo.

Utomo, B. (2006). Ekologi Benih. Published On http://library.usu.ac.id/download/D iakses Tanggal 25 Maret 2018 Pukul 20.17 Wita 